\title{
RENEWABLE ENERGY RESOURCES IN AGRICULTURE: POTENTIAL AND LEGAL FRAMEWORK IN THE REPUBLIC OF SERBIA
}

\author{
Nadežda Ljubojev ${ }^{1}$, Marijana Dukić-Mijatović2 ${ }^{2}$ Željko Vojinović3 \\ *Corresponding author E-mail: nadezdaljubojev@gmail.com
}

\begin{abstract}
A R T I C LE I N F O
Review Article

Received: 10 August 2018

Accepted: 12 September 2018

doi:10.5937/ekoPolj1803227L

UDC 620.91:328.431(497.11)

Keywords:

Renewable energy resources, agriculture, legal framework, biomass, Serbia.

JEL: Q4, K32

\section{A B S T R A C T}

The disappearance of natural resources, development of environmental awareness and need to rationalize their spending, and in order to reduce the cost of energy production, caused an increasing need for the development and use of renewable energy sources (RES).Larger use of RES would provide energy security and lower energy imports.Of all forms of RES in R. Serbia, the biomass energy potential comes first.There has been considered legal framework relevant to the use of RES at the European level and within the boundaries of the R. Serbia. The authors point to the need for further harmonization of domestic legislation with global and European trends in the field of RES, as well as obligations from ratified international documents and the European integration process. The article also shows the potential of RES in agriculture as well as the actual state of exploitability in R. Serbia. Increasing the use of RES in R. Serbia can help diversify Serbian's energy supply, create growth and jobs, and lower greenhouse gas emissions.
\end{abstract}

(C) 2018 EA. All rights reserved.

\section{Introduction}

The climate change will significantly determine energy policy in the world in the course of the $21^{\text {st }}$ century. Protection of global climate, valuable sources saving and feasible development in the whole world are important challenges which must be overcome in this century (IEA, 2015). Fossil fuel reserves are limited. Statistical reserves of oil are

1 Nadežda Ljubojev, Ph.D., Associate Professor University of Novi Sad, Technical Faculty “Mihajlo Pupin”, Đure Đaković, 23000 Zrenjanin, Serbia, Phone: +381 23550 520, E-mail: nadezdaljubojev@gmail.com. ORCID ID (https://orcid.org/0000-0001-9991-6702).

2 Marijana Dukić-Mijatović, Ph.D., Full Professor, University of Business Academy, Law Faculty of Economics and Justice, Novi Sad,21000 and University Novi Sad, Faculty of Economy in Subotica, Segedinski put 9-11 24000 Subotica, Republic of Serbia, Phone: +38163542093, E-mail: marijana.dukic.mijatovic@gmail.com

3 Željko Vojinović, Ph.D., Assistant professor, University Novi Sad, Faculty of Economy in Subotica, Segedinski put 9-11 24000 Subotica, Republic of Serbia, Phone: +381648832600 , E-mail: zv@inbajmok.com 
calculated to be sufficient for some 30 years more, gas reserves for about 60 years and coal reserves for about 200 years more (Pekez et al., 2016). The increase in the price of fossil fuels, emissions of carbon dioxide and other gases that cause the greenhouse effect and climate changes will make people reduce the energy consumption.

RES is a promising alternative solution because it is clean and environmentally safe. It also produces lower or negligible levels of greenhouse gases and other pollutants when compared with the fossil energy sources they replace (Demirbas, 2009). Promoting innovative renewable applications and reinforcing the renewable energy market will contribute to the preservation of the ecosystem by reducing emissions at local and global levels (Abdeen, 2008).The technically usable energy potential of the RES in R. Serbia is very important and has been estimated to over 4.3 Mtoe per year, which makes about $20 \%$ of the total primary energy consumption (Pekez et al., 2016). R. Serbia is considered to have the potential to produce 4.89 Mtoe from RES. Renewable energy has the potential to play an important role in providing energy with sustainability to the vast population in developing countries which still have no access to clean energy (Painuly, 2001).

In order to implement the green economy, it is important that the citizens are aware of the environment, but also the laws that the country's government will adopt to support the development of the concept of the green economy (Hanić, Baranenko, 2014). Around the world, a growing number of nations have recognized the economic, social, and environmental benefits of renewable energy, and are enacting tax incentives and other policy measures favorable to renewable technologies (Liu et al., 2009).Projections are important tools for long-term planning and policy settings (Demirbas, 2009).

Getting energy from agriculture is not a negligible factor in the struggle for the energy stability of each state, and besides food production, this economic activity could become the main producer of energy from renewable sources (Roljević, Hamović, 2010). The largest share of the RES in our country has biomass, and it accounts for $61 \%$ of the total RES potential. According to statistical data, using the available RES potentials, the need for non-renewable sources would be reduced by about $45 \%$, and import dependency by about $20 \%$.

Given that the R. Serbia achieves as much as $20 \%$ of the social product from the agroindustry, while agricultural production participates in the creation of GDP with 12\%, there is a need to direct agriculture towards the production of RES (Roljević, Hamović, 2010). With the transition of agricultural holdings to the production of RES, it would encourage the development of rural economy, provide energy needs, and thus reduce import dependency. RES as a significant potential of the agrarian sector should be used in the direction of development of rural environments, as well as reduction of dependence on fossil fuels.

\section{Renewable energy sources in agriculture}

As already mentioned, technically usable energy potential of RES in R. Serbia is large and it is estimated at over 4.3 Mtoe per year - of which about 2.7 Mtoe per year is in the 
biomass utilization, 0.6 Mtoe per year in unused hydro-potential, 0.2 Mtoe per year in existing geothermal sources, 0.2 Mtoe per year in wind energy and 0.6 Mtoe per year in the exploitation of solar energy. The development and scope of the use of RES in agriculture in R. Serbia are determined by the following factors:

- Geographical position;

- Natural resources (climate, pedological and hydrological characteristics);

- $\quad$ The technical and technological degree of social development;

- $\quad$ Educational level and environmental awareness of people;

- $\quad$ Economic abilities of the state;

- $\quad$ Financial possibilities of family farms;

- $\quad$ Administrative and legal regulations in the field of RES use;

- $\quad$ Long-term global and European rural development strategies and the fight against the negative effects of climate change.

1) Wind Energy. R. Serbia has all the potentials for exploiting wind energy. The most promising locations in R. Serbia for the construction of wind power plants based on wind speed are: Midžor on Stara Planina with average wind speed of $7.66 \mathrm{~m} / \mathrm{s}$, Suva Planina 6.46m / s, Vršački Breg 6.27m / s, Tupižnica $6.25 \mathrm{~m} / \mathrm{s}$, Krepoljin $6.18 \mathrm{~m} / \mathrm{s}$, Deli Jovan $6.13 \mathrm{~m} / \mathrm{s}$, Juhori Jastrebac, but also other areas in the Danube, Sava and Morava valley should not be omitted.

The prescribed quotas of the Government of the Republic of Serbia for the wind power plant by 2020 amount to $500 \mathrm{MW}$. Considering the maximum possible production of wind farms with this installed power, they can count on their maximum technically usable potential of 1,200 GWh / year (0,103 Mtoe / year). The incentive fixed feed-in tariffs for wind farms amount to 9.2 eurocent / $\mathrm{kWh}$, with a guaranteed 12-year power takeover period. In R. Serbia, as much as $70 \%$ of the total production of wind energy is produced in the winter months when the country imports most and when the import of electricity is the most expensive.

The first wind farms in R. Serbia were built in the last decade. However, the construction of large wind farms in R. Serbia obviously belongs to the future. During the period 2008-2018, the total installed capacity of preferential generators was 17.0 MW, and wind farms acquired the status of temporary preferential generators with a total capacity of 514 MW (according to the data of the Ministry of Mining and Energy of Republic of Serbia (MMERS, 2018). Further work on improving the existing solutions needs to be done by taking into account the new results of wind energy measurement and more precise digital maps in R. Serbia.

2) Hydro energy. R.Serbia has significant hydro potential that is estimated at $25 \mathrm{TWh}$ per year, of which 17.5 TWh is identified annually as economically viable for use. Almost $10 \mathrm{TWh}$ are already being used, mainly through large hydroelectric power plants (according to the data of Chamber of Commerce of Serbia. (CCS, 2018). 
Small hydropower plants have energy facilities of up to $10 \mathrm{MW}$ and fall into the category of privileged energy producers. The energy potential of watercourses and locations for the construction of small hydroelectric power plants was determined by the document Cadastre of Small Hydroelectric Power Plants on the territory of SR Serbia outside $S A P$ from 1987. Unused hydropower potential is mostly on smaller rivers.In about 900 potential locations on the rivers in R. Serbia, including small rivers, the building of small hydroelectric power plants (up to $10 \mathrm{MW}$ ) has been established with possible production of about $1,800 \mathrm{GWh}$ per year.

3) Geothermal energy. Geothermal energy is used only in some reservoirs and agricultural enterprises. This is a legally underdeveloped area with old and energyinefficient equipment, but for which there is a private initiative (CCS, 2018).

R. Serbia has a rich geothermal potential that is very poorly used. The geothermal potential of the R. Serbia represents a large number of spas and natural springs with water temperatures greater than $30^{\circ} \mathrm{C}$, and a different degree of natural diversity. In R. Serbia, geothermal areas are mostly developed in Vojvodina, with the highest temperature of Vranjska, Jošanička and Sijerinska spas (Despotović et al., 2016).The potential of existing drill holes in R. Serbia (without using thermal pumps) is 0.17 Mtoe. There are more than 50 sources of the capacity that exceeds $1 \mathrm{MW}$. There are natural and artificial thermal water sources in R. Serbia in more than 60 municipalities. The temperature of the water most frequently rises to $40^{\circ} \mathrm{C}$ and in the territory of six municipalities, it is over $60^{\circ} \mathrm{C}$.

4) Sun energy. Sun energy represents the energy potential of the R. Serbia which can be used for the production of heat or electricity; however, the solar potential is unused. On most of the territory of the R. Serbia, the number of hours of solar radiation is significantly higher than in many European countries (between 1,500 and 2,200 hours per year), but the use of this energy is still far behind EU countries. ${ }^{4}$ The average intensity of the solar radiation in the territory of the $\mathrm{R}$. Serbia ranges from $1.1 \mathrm{kWh} / \mathrm{m} 2$ per day in the north to $1.7 \mathrm{kWh} / \mathrm{m} 2$ per day in the south during January, and from 5.9 to $6.6 \mathrm{kWh} / \mathrm{m} 2$ per day during July. Yearly average value of global radiation energy for the territory of the R. Serbia is $1,200 \mathrm{kWh} / \mathrm{m} 2$ in northwest Serbia and $1,550 \mathrm{kWh} / \mathrm{m} 2$ in southeast Serbia, while in its central part it is about $1,400 \mathrm{kWh} / \mathrm{m} 2$ per year (ESDSRS, 2015).

Because of the geographical position of the R. Serbia and moderate continental climate in our country, which means relatively sharp winters with average temperatures during the coldest winter months are often lower than $0^{\circ} \mathrm{C}$ and relatively high demands for thermal energy just in the period when the sun's radiation is weakest it is possible to use solar heating systems (SGS) as basic, but only as an additional heating system. Analyzes have shown that optimally designed SGS for the territory of the R. Serbia should satisfy only $10-20 \%$ of the demand for thermal energy for space heating (System technology for solar thermal", Technical information 897600 RS, Rehau Solect, April, 2010).

4 The energy that the sun emits on the $1 \mathrm{~m}^{2}$ roof of the house in R. Serbia during the year is equal to the energy generated by the combustion of 130 liters of oil - and it is free (Despotović et al., 2016). 
This small percentage of satisfying the heating needs has determined their second and foremost role, both in R. Serbia and in the world for the heating of consumable water. Also, due to the existing legal regulations, as well as the geographical position of the R. Serbia and the moderate continental climate that governs this area, it can be concluded that the construction and exploitation of small and medium-sized SGS is the optimal choice for investors (Jefferson Instiute, 2009).

5) Biomass. Biomass represents a significant energy potential of the R. Serbia from agriculture and forestry. Today, annual biomass production in R. Serbia amounts to about 12.5 million tons (2.90 Mtoe) - 1.56 Mtoe is agricultural biomass and 1.34 Mtoe makes forest biomass. R. Serbia, and especially its northern region Vojvodina has a relatively big potential of biomass which is produced as a surplus in primary agricultural production (Tolmac et al., 2016). However, the CCS considers that the biggest obstacles to the increased use of biomass are mainly used as straws in stables, while private farms often burn the biomass in the fields (CCS, 2018) The market for the sale of biomass products in R. Serbia is poorly developed or does not exist and the fragmentation of the property is increasing the collection and transport costs of biomass. The use of biomass is mainly based on the remains of agriculture and forestry. Although the biomass potential is available throughout the territory of the R. Serbia, however, wood biomass is mostly located in central Serbia and agricultural biomass in the area of Vojvodina. However, while the degree of utilization of wood (forest) biomass potential is relatively high $(66.7 \%)$, the potential of agricultural biomass is slightly used $(\sim 2 \%)$, while the potential of biodegradable municipal waste is not used at all (ESDSRS, 2015).However, in theory, biomass is increasingly considered to be among the rest of the RES due to the fact that it is sufficiently similar to fossil fuels and that they can be directly replaced. According to some estimates, if the rapeseed were grown on 150,000 hectares, the production on these areas would be sufficient to produce about 100,000 tons of biodiesel (Ilić et al., 2004).

The largest share in the RES in our country has a biomass which represents a degradable part of products, that is residues and waste from agriculture, forestry and wood industry, whether they are plant or animal origin, whereby their energy use is permitted only in accordance with the regulations governing issues of environmental protection (Roljević, Hamović,2010). Large quantities of biomass originate from agriculture, cultivation of cereals, industrial and fodder plants, then from residues of fruit tree crops, as well as farm residues. ${ }^{5}$ For example, about 10 to $12 \mathrm{~kg}$ of liquid manure with 4 to $10 \%$ dry matter is needed to obtain $1 \mathrm{~m} 3$ of biogas (Furman et al., 2007).Of all RES forms, the biomass energy potential is at the forefront. The biomass potential is very large and very widespread throughout the world. Today, biomass is a major source of global energy needs, and it reaches 12\% (50 EJ / year) of global demand (406 EJ / year) (Despotović et al., 2016).

5 With fruit trees, every season, a large number of plant residues 1-2 $t$ / ha are obtained, which are most often burned, or rarely shed. A similar situation is in viticulture, where every year about $1 \mathrm{t}$ / ha of residue remains (Roljević, Hamović,2010). 
R. Serbia has very favorable conditions for the cultivation of oil plants, above all sunflower, soybean, and rapeseed whose seeds are abundant with the oils needed for the production of biodiesel. Facilities for the production of electricity and heat from biomass, as well as biodiesel and bioethanol, have been tested abroad for good practice and the future, using the potential of local agriculture and industry (Tešić et al., 2010).

Implementing bioenergy plants have positive impacts on rural development by creating direct employment and by supporting related industries and employment there. Jobs are created all along the chain, from biomass collection in the forest or energy crops grown by farmers to transport, conversion technology providers, installers and service providers, marketing, etc (Kaygusuz et al., 2007).

\section{The legal framework in the European Union}

The European Union (EU) has set itself ambitious goals when it comes to the use of RES and the fight against climate change. It is estimated that the EU is currently the world leader in investing in RES, especially in the development of wind and solar energy. At the end of 2014, $128.8 \mathrm{GW}$ of total wind capacity (120.6 GW onshore and 8 GW at sea) was produced in the EU, which is average $284 \mathrm{TWh}$ annually - enough to cover $10.2 \%$ of electricity consumption in the EU (EWEA, 2015). The European Commission's 2005 Biomass Action Plan (2005) stressed that support for the development of RES, such as biomass, is very important for the development of rural areas.

The EU integrates climate and energy issues through the EU Climate and Energy Package 2020, which includes a set of binding legal documents. The 20-20-20 targets set three key targets for the EU by 2020: reducing greenhouse gas emissions by $20 \%$ compared to 1990 levels; increasing the share of energy consumption from RES to $20 \%$; and increasing energy efficiency by $20 \%$. These goals represent an integrated approach to climate and energy policies aimed at combating climate change, increasing EU energy security, strengthening its competitiveness and ensuring efficient use of energy. The EU Climate and Energy Package consists of four legislative acts:

- The EU Emission Trading System-ETS system is a means to reduce greenhouse gas emissions from the industrial sector in an economically efficient way, and is currently in the third trading period for the period 2013-2020. The climate and energy package includes a comprehensive revision and strengthening of the legislation underlying the EU ETS system i.e. the EU Emissions Trading Directive. The changes include the introduction of a unique EU-wide emission limit instead of previous national restrictions. This limit will be reduced each year so that by 2020, emissions are $21 \%$ below the 2005 level.

- Under the Decision on Joint Efforts, Member States have undertaken binding annual targets for reducing their greenhouse gas emissions from sectors not covered by the EU ETS, such as agriculture, housing, waste, and transport accounting for around $60 \%$ of the total emissions in the EU. 
- EU Member States have undertaken binding national targets to increase the share of RES in their total energy consumption by $2020 .{ }^{6}$ Directive 2009/28 / EC provides that, by 2020 RES shall account for at least $20 \%$ of the total energy consumption in the EU. This Directive also provides that, by 2020 the use of renewable energy in transport (biofuel, electricity, and hydrogen produced from RES) amounts to at least $20 \%$ of the total fuel consumption in the EU.

- The fourth element of the climate and energy package is a directive that creates a legal framework for the environmentally sound application of carbon capture and storage.

The climate-energy package does not deal directly with energy efficiency targets. This goal is accomplished through Energy Efficiency Plan (2011).

Biofuels and bioliquids are instrumental in helping EU countries meet their 10\% renewables target in transport. The Renewable Energy Directive 2009/28/EC sets out biofuels sustainability criteria for all biofuels produced or consumed in the EU to ensure that they are produced in a sustainable and environmentally friendly manner. ${ }^{7}$ Biofuel concuption has increased nine-fold over 15 years and by $2030,60 \%$ of RES willbe supplied from biofuels and will be used in all sectors (Bozma, Akda, 2018).

The EU has set goals for 2030 that are even more ambitious and demanding than the 2020 targets. This framework aims to build a competitive and secure energy system that should provide affordable energy for all consumers, increase the energy security of EU energy, reduce dependence on energy imports and provide new opportunities for development and employment. (EC,2017). The 2030 Framework for Climate \& Energy sets three key targets for the year 2030. The first key objective is the obligation to reduce greenhouse gas emissions for 2030, at the EU level by at least $40 \%$ below the level of $1990 .{ }^{8}$ The European Council has adopted an obligation to increase the share of RES by at least $27 \%$ in total energy consumption at the EU level by 2030 , which is the second key objective. The third goal is to increase energy efficiency by at least $27 \%$.

6 These targets reflect different Member States' starting points and the potential for increasing RES outputs ranged from $10 \%$ in Malta to $49 \%$ in Sweden. According to the available estimates, with regard to the increase in the final energy consumption from RES, the EU will achieve $21 \%$ and in this case exceed its 2020 target (the achieved level of RES use ranges from $0.3 \%$ in Malta to $52.4 \%$ in Sweden (where the national target is exceeded).

7 The European Commission has issued non-binding recommendations on sustainability criteria for biomass. Related documents on Sustainability criteria: Report on sustainability requirements for the use of solid and gaseous biomass sources in electricity, heating and cooling [COM/2010/11]; Impact Assessment [SEC/2010/65] and Summary of the Impact Assessment [SEC/2010/66].

8 In order to achieve the $40 \%$ target, the sectors that fall under the EU ETS system should reduce emissions by $43 \%$ compared to 2005 . Emissions from non-EU sectors. The ETS should reduce emissions by $30 \%$ below 2005 levels. 
The Roadmap by 2050 is a set of policy plans that should enable sustainable use of resources at the EU level. The Roadmap suggests that by the year 2050, the EU at the national level should reduce emissions by $80 \%$ compared to 1990 levels. To make the transition, the EU would need to invest an additional $€ 270$ billion (or on average $1.5 \%$ of its GDP annually) over the next 4 decades (EC, 2017).

\section{Treaty on establishing the Energy Community}

R. Serbia has ratified the Treaty on establishing the Energy Community between the European Community and the Albania, Bulgaria, Bosnia and Herzegovina, Croatia, FYR Macedonia, Montenegro, Romania, Serbia and the United Nations Interim Mission Kosovo in accordance with UN Security Council Resolution 1244,2006 "Official Gazette of the R. Serbia, No. 62/2006"). However, in December 2009, the Council of Ministers of the Energy Community decided to join Moldova and Ukraine, thus abolishing the geographical concept of the Western Balkans, for which the process was initially tied. The main task of the Energy Community is to establish cooperation between the signatory countries and to create a stable regulatory and market framework attractive for new investments in transit and transport electricity infrastructure and in the production of energy.

The main objective of the Treaty establishing the Energy Community is to harmonize the energy policies of non-EU countries with the EU's energy policy. The Energy Community allows the transfer of essential energy acquis communautaire, assistance in the development of an adequate regulatory framework and liberalization of the energy markets of the parties in accordance with the acquis. An important element is also the implementation of the EU 20-20-20 targets by signatories to the Treaty establishing the Energy Community, although they are not part of the EU. The goal of forming the Energy Community is to create a single energy market, increase energy efficiency and the degree of use of RES.

The energy strategy of the Energy Community is based on the same principles as the EU Energy Strategy, setting priorities and goals for the energy sector: creating an energy market with competitive prices, ensuring energy security, reducing $\mathrm{CO} 2$ emissions, and saving energy. The first objective is to establish a competitive integrated energy market between the contracting parties and its integration with the EU energy market. The second strategic objective is to attract investments in the energy sector, and the third strategic goal is to secure and sustainably supply electricity to customers.

The Ministerial Council of the Energy Community in 2012 adopted Directive 2009/28/ EC and set national targets for RES according to which nine contracting parties are obliged to achieve by 2020. Thus, the Energy Community of R. Serbia has set a mandatory goal to increase the share of RES in total gross energy consumption, starting from $21.2 \%$ in 2009 to $27 \%$ by 2020 . In the electricity sector, $1,092 \mathrm{MW}$ of new RES generation capacities is required by 2020 . However, with regard to the implementation of Directive 2009/28/ EC, most of the Contracting Parties of the Energy Community will not be able to fully comply with and implement the acquis on time. 
However, the use of RES in the R. Serbia is far below the expected results that the R. Serbia, as a Contracting Party of the Energy Community, committed. This result is not a consequence of the lack of potential, nor of the lack of investors, but of a large number of different economic, political and social obstacles that are on the road to the construction of RES projects, especially large ones. Therefore, the obstacles that arise are legal and regulatory barriers; institutional and administrative barriers; financial and investment barriers; barriers to capacity and infrastructure; limited public awareness and public acceptance of RES.

\section{The legal framework in the Republic of Serbia}

R. Serbia signeda Stabilisation and Association Agreement between the European Community and their Member States on the one side and Serbia, on the other side ("Official Gazette of RS - International agreements 83/08"). In this way, it aligns its legal system with EU acquis communautaire acquis in order to achieve the goals of the EU in the field of RES, fulfill its international obligations and provide a better energy future. However, this will be possible if the regulatory framework and other investment conditions encourage continuous investment in this area.

A new Law on Energy ("Official Gazette of the R. Serbia, No. 145/2014“) was adopted in the Republic of Serbia (LE, 2015), a new Energy Sector Development Strategy of the Republic of Serbia for the period by 2025 with projections by 2030 (ESDSRS, 2015) ("Official Gazette of the R. Serbia, No. 101/2015") and National Action Plan for Renewable Energy Sources (NAPRES, 2013)

- Making of NAPRES (2013) came from an international obligation that the R. Serbia took over the Treaty establishing the Energy Community. In NAPRES as a framework for the promotion of energy produced from RES in R. Serbia, mandatory national targets for RES energy participation in gross final energy consumption (27\%), as well as the share of energy from RES in transport $(10 \%)$ by 2020 , are set. In this way, R. Serbia joined the countries that subsidized electricity generation from the RES and introduced the most widespread model - incentive fixed feed-in tariffs.

- ESDSRS (2015) sets a framework aimed at facilitating investment and promoting energy security at the national and regional levels.

- LE (2015) has largely implemented the Third EU Energy Package, and set targets for energy policy, reliable, high-quality and safe energy and energy supplies; goals for the use of RES; conditions and incentives for RES production. LE made positive changes in the following areas: Introduction of a single Electricity Purchase Agreement; The deadline for completion of the project is extended to three years (instead of two); A clause vis maior was defined during construction; The manner of obtaining licenses and construction, as well as the obligations related to the connection of energy facilities (overhead lines and substations) that are financed and potentially built by private investors were defined, but are 
owned by the state transmission system operator that manages them. And the LE fees on issues of authorization and tenders for the construction of new production capacities are harmonized with the acquis. (ECS, 2015)

- The Law on Planning and Construction ("Official Gazette of the R. Serbia, No. 72/2009, 81/2009 - exp., 64/2010 - decision US, 24/2011, 121/2012, 42/2013 - decision US, 50/2013 - decision US, 98/2013 - decision US, 132/2014 and $145 / 2014$ "), which simplifies the process of obtaining building permits, was adopted by the Assembly of the Republic of Serbia in December 2014.

- Regulations that represent the legal framework for further development and implementation of energy projects from the RES are: Decree on the Requirements and Procedure for Acquiring the Status of a Privileged Producer, Preliminary Privileged Producer and Producer from RES („Official Gazette of R. Serbia 56/2016 '); Decree on the Conditions and Procedure for Obtaining the Status of Privileged Electricity Producer, Temporary Privileged Producer and Producer of Electricity from RES, („Official Gazette of R. Serbia, 56/2016“) and Decree on Power Purchase Agreement („Official Gazette of R. Serbia, 56/2016“).

- In the Republic of Serbia was adopted: (a) Report on the implementation of the National Action Plan for the Use of Renewable Energy Sources, MMERS, "Official Gazette of RS", no. 8/15; (b) Report on the implementation of the National Action Plan for the Use of Renewable Energy Sources of the Republic of Serbia, 2016, MMERS.

The Energy Agency of the Republic of Serbia is responsible for issuing and revoking the license for performing the activity of electricity generation and combined generation of electricity and heat from the RES. In further legislative activities, it is necessary to assess the possibility of rationalizing procedures for obtaining licenses and permits, as they are often long and sometimes contradictory.

The Republic of Serbia is a member and founder of the International Renewable Energy Agency (IRENA) whose main goal is to become the main driving force in the accelerated transition towards the widespread and sustainable use of RES, and its main activities include: providing concrete advisory services to governments industrialized for RES policy, transfer technology and consulting services related to project financing, construction, and production capacity in the field of RES use.

However, each of the RES has its own specific environmental impact, which must be carefully analyzed in order to avoid harmful consequences. Thus, investors must strictly adhere to the standards in the construction of the wind farm, taking particular account of the distance of the wind farm from populated areas, and in the domain of impact studies on bird and bird habitats. 


\section{Conclusions}

With the strengthening of ecological awareness of the disappearance of natural resources, and the rationalization of their spending, and in order to reduce the cost of energy production, there is an increasing need for development and use of RES, striving for a green growth of the economy. The RES will contribute to the energy security of the R. Serbia and countries in the region, and will significantly reduce winter imports of electricity and energy. The need for diversification of energy sources became apparent more than ever in May and June 2014, when the region hit the worst floods ever.

R. Serbia has established important components of the institutional and legal framework in this area. At the same time, there is still a need for their improvement, but above all by the implementation. The Government of the Republic of Serbia has developed a strategy to align its legislation and energy policy with the Directive 2009/28/EC, in an effort to fulfill international obligations. What is needed is to integrate the legal and political framework for the period up to 2030, which would provide regulatory security for investors and a coordinated regional approach. In order to encourage development and investments in this sector and fulfill the obligation under the Energy Community Treaty, the Government of the Republic of Serbia has adopted several regulations in accordance with Directive 2009/28 / EC, including: establishing a system of $\gg$ incentive tariffs « in which the Government of the R. Serbia subsidizes the consumption of renewable electricity; defined requirements for acquiring the status of $»$ privileged electricity producer« that uses RES for electricity generation.

Increased use of RES in agriculture for energy production will lead to the creation of new opportunities for production, placement and income in agriculture and forestry, as well as the development of the machinery industry and investment equipment, the opening of new jobs, primarily in small and medium enterprises and development companies. Therefore, staffing capacity, financial resources, as well as public sensitivity are essential for the need for RES development. Further use of RES will also be an investment in new jobs, as well as environmental protection as one of the key requirements for the EU accession.

International trends show that demand for energy is moving towards higher demand for cleaner fuels, so RES is a development and export opportunity, as natural resources allow it. In order for these resources to be available for energy generation, infrastructure construction, as well as diversification and adaptation of agricultural production and support to rural development, is necessary. The aim is to develop innovative ways of production, improve infrastructure and create new employment opportunities, so the potential of the RES derived from agriculture must be directed towards the development of agriculture and villages.

\section{Conflict of interests}

The authors declare no conflict of interest. 


\section{References}

1. Abdeen, M. O. 2008). Energy, environment and sustainable development. Renew. Sust. Energ. Rev. (12) 2265-2300.

2. Annual Implementation Report 2016/2017, Energy Community Secretariat, 1 September 2017. Vienna, Austria.

3. Bozma, G., \& Akda, M. (2018). Biofuel and Agricultural Commodity Prices Gürkan Bozma \& Murat Akdaö. Selected Studies on Economics and Finance, 224.

4. Communication from the Commission to the European Parliament, the Council, the European Economic and Social Committee and the Committee of the Regions Energy Efficiency Plan 2011 [COM/2011/0109 final].

5. Communication from the Commission to the European Parliament, the Council, the European Economic and Social Committee and the Committee of the Regions Energy Roadmap 2050 [COM/2011/0885 final].

6. Demirbas, A. (2009). Global renewable energy projections. Energ. Source. Part B (4) 212-224.

7. Directive 2009/28/EC of the European Parliament and of the Council of 23 April 2009 on the promotion of the use of energy from renewable sources and amending and subsequently repealing Directives 2001/77/EC and 2003/30/ EC. Official Journal of the European Union, L140, 5.6.2009, p. 16-62.

8. Despotović Ž., Jovanović M. \& Stevanović I. (2016). Possibility to use the OIE in agriculture in R. Serbia, International Scientific Conference, Sustainable Agriculture and Rural Development in Functioning of the Strategic Goals of the Republic of Serbia within the Danube Region Development and Application of Clean Technologies in Agriculture, Belgrade 14-15 December. [in Serbian: Despotović Ž., Jovanović M. \& Stevanović I. Mogućnost korišćenja OIE u poljoprivredi u R. Srbiji, Međunarodni naučni skup, Održiva poljoprivreda i ruralni razvoj u funkciji ostvarivanja strateških ciljeva R. Srbije u okviru Dunavskog regiona - razvoj i primena čistih tehnologija u poljoprivredi].

9. European Commission, 2017. https://ec.europa.eu/clima/policies/ strategies/2050 en. (July 31, 2018)

10. Energy Community Secreteriat (ECS) 2015. Annual Implementacion Report 2016-2015.

11. Furman, T., Nikolić, R., Tomić, M., Savin., L, Simikić, M. (2007). Alternative Renewable Energy Sources in Agriculture, Tractors and Drives, 12, (3) 7-10; Novi Sad. [in Serbian: Alternativni obnovljivi izvori energije u poljoprivredi, Traktori i pogonske mašine, 12, (3)7-10; Novi Sad].

12. Hanić, A. \& Baranenko, E. (2014). Green economy - the influence of wind energy on the economy, Ecologica, 21, (74) 129-135. 
13. Ilić, M, Grubor, B, Tešić, M. (2004). The State of Biomass Energy in Serbia, Thermal science: 8, (2) 5-19.

14. Jefferson Instiute: Korišćenje solarne fotonaponske energije u Srbiji, Beograd, Decembar, 2009.

15. Kaygusuz, K, Yüksek, Ö, \& Sari, A. (2007). Renewable energy sources in the European Union: Markets and capacity. Energy. Source. Part B (2)19-29.

16. Liu, Q., Miao, Q., Liu, J. L, and Yang, Y. (2009). Solar and wind energy resources and prediction. Journal of Renewable and Sustainable Energy (1) 043105.

17. Ministry of Mining and Energy of Republic of Serbia (MMERS, 2018) http:// www.mre.gov.rs/doc/registar040518.html\#sec vetar. (July 31, 2018)

18. Nakomcic-Smaragdakis B., Stajic T., Cepic Z., and Djuric S. (2012). Geothermal energy potentials in the province of Vojvodina from the aspect of the direct energy utilization. Renew. Sust. Energy. Rev. (16) 5696-5706

19. Painuly, J. P. (2001). Barriers to renewable energy penetration; a framework for analysis. Renew. Energy. (24) 73-89.

20. Pekez, J. Radovanovic, Lj. Desnica, E. \& Lambic M. (2016). The increase of exploitability of renewable energy sources, Energy Sources, Part B: Economics, Planning, and Policy, (11)1, 51-57.

21. Roljević S, Hamović V. (2010). The Importance of Agriculture in Strengthening Serbian Energy Potentials, Economic Issues, (2) 80-130. [in Serbian: Roljević S, Hamović V. (2010). Značaj poljoprivrede u jačanju energetskih potencijala Srbije, Ekonomske teme].

22. Tešić M, Igić S., \& Adamović D. (2006). Energy Production - a new task and a source of income for agriculture, Contemporary Agricultural Technique, 32, (1-2)1-9. [in Serbian: Tešić M, Igić S., Adamović D. (2006). Proizvodnja energije - novi zadatak i izvor prihoda za poljoprivredu, Savremena poljoprivredna tehnika, 32, (1-2) 1-9.]. 